\title{
LEARNING CONTENT OF ISLAMIC EDUCATION BASED ON MULTIKULTURAL IN SENIOR HIGH SCHOOL IN BANDAR LAMPUNG
}

\author{
Agus Pahrudin', Syafrimen², Heru Juabdin $\mathrm{Sada}^{3}$ \\ agus.pahrudin@ @adenintan.ac.id, syafrimen@ radenintan.ac.id, herujuabdin@ radenintan.ac.id \\ ${ }^{1,2,3}$ Universitas Islam Negeri Raden Intan Lampung
}

\begin{abstract}
This study aims to describe how Multicultural Content-Based Islamic Educational Content. The research is run using a descriptive-qualitative approach (multi-case multi-site). The data were collected through in-depth interviews to two experts of Islamic education and focus group interviews to four teachers who have had work experience of seven to twenty years. Furthermore, the data were analyzed qualitatively using NVIVO 10.0 software. The results of the research show that the content of Islamic-Based Multicultural Education Learning is: Explaining the concept of aqidah and muamalah, Designing material by applying multicultural and emphasizing on equality principle, Making culture as Content, and Rahmatalillalamin Islam concept.
\end{abstract}

Keywords: Learning content; islamic education; and multikultural

\section{INTRODUCTION}

If you look at the conditions of the Indonesian people themselves, they are very plural in nature. As stated by the founders of the Indonesian state in the slogan "Bhineka Tunggal Ika" manifests a multicultural face reality. It is above this pluralistic society that the NKRI has been successfully built and can stand tall, strong today. The term "unity" in the NKRI as the incarnation of Unity in Diversity does not only mean physical, but psychological and cultural. Not also in the sense of atomistic aggregation and structural integration, but unity which has the highest degree of cultural integration, which contains national solidarity based on the core values of a shared life. Since the ancestors of these basic values have been made the principle of life and even a view of life. Objectively, the plurality face of Indonesian society has a unique form and structure, therefore national education must have an insight into the development of Indonesian community plurality (Widisuseno, 2012).

Viewed from the socio-cultural, religious and geographical conditions are so diverse and extensive. The issue of religious education, in the context of plural Indonesia nation, multicultural, multiethnic, and multi-religion becomes a crucial issue. Therefore, the serious attention is needed from various elements so it is not to potentially to the unity, the nation's development of Islamic Education will decrease the 
process of democratization growth in the life of nation and state that began to develop after reformation era at 1998. Although the current issue is letting up now, it does not mean that the problem is solved by itself, because in some cases in the level of implementation of article 13 A of the National Education System Law is not working properly. Many Muslims regret that private Christian schools still do not provide Muslim religious educators to Muslim learners who majority learned in that school. The issue of religious education in the Sisdiknas Law is of course a latent dangerous that threatens not only the continuity of national education in the future, but also the relationship between Muslims and Christians in Indonesia (Harto, 2014).

Pluralism, on the one hand, is a beautiful social power and diversity when one with another synergizes and works together to build a nation. However, diversity can be a trigger for conflict and violence that can destabilize the joints of the life of the nation and state if it is not managed properly and well (Kosim, 2010).

Etymologically the term multiculturalism comes from multi (many), culture (culture), isme (view-ideology) or the notion of plural cultures and as opposed to monoculturalism or a single cultural notion. Essentially, the term contains an acknowledgment of the dignity of humans who live in their communities with their respective cultures. Every individual feels valued and feels responsible for living with his community. A society's denial of the need to be recognized (politics of recognition) is the root of all inequality in various fields of life (Widisuseno, 2012).

In simple multicultural means cultural diversity (Lash \& Featherstone, 2002). In the Big Indonesian Dictionary, multiculturalism is defined as a symptom in a person or a society characterized by the habit of using more than one culture (Nasional, 2005). There are three terms that are often used to describe diverse societies (religions, races, languages, and different cultures), namely plurality, diversity, and multicultural.

As an idea, multiculturalism was first discouraged in America and Western European countries in the 1960 s by movements which demanded the attention of civil rights movements. The main purpose of this movement is to reduce discriminatory practices in public places, at home, at work, and in educational institutions, which are carried out by the majority against minority groups. During that time, in America and Western European countries, there was only one culture known, namely white Christian 
culture. The other groups in the community are grouped as minorities with restrictions on their rights (Nasional, 2005).

Education is the development of various human potential so that his life can be in line with nature and sunnatullah. One of the functions of education is a social function, which is to introduce and condition students to accept and be ready to live in a difference in peace and harmony (Mulyana, 2011). Islamic Education (PAI) is an education which the theories are compiled based on Al-Qur'an and Hadith (Tafsir, 2004). In High School Education (SMA), (Nasional, 2005) proposed that "Islamic Education is a consciousness planned effort in preparing learners to know, understand, live up to believe, piety, and morality in practicing to be Moslem as guided by the holy book of the Qur'an and Hadith, through guidance activities, teaching, practice, and the use of experience, coupled with guidance to respect the followers of other religions and life in harmony among other religion people in society until appear the unity of the nation".

The education of Islam is actually a subject that reflects the doctrine of the teachings of Islam. The curriculum has been designed according to the systematics of Islamic teachings which include aqidah, ibadah, and akhlak. In conjunction with multiculturalism some pie material that needs to be taught with great emphasis is as follows the teachings on compassion, teachings abo (Harto, 2014).

If it is associated with Islamic Education as a field of study, according to Zakiuddin Baidhaw, there are seven paradigmatic assumptions of multicultural Islamic Education, namely: educating students to: learn to live in diversity, build mutual trust, maintain mutual understanding, uphold mutual respect ( mutual respect), open in thinking, appreciation and interdependence, conflict resolution and non-violent reconciliation (Baidhawy, 2008).

Many studies have been conducted regarding multiculturalism including: Implementation of multicultural education in the practice of education in Indonesia (Supriatin \& Nasution, 2017), the urgency of Islamic religious education in the development of multicultural values (Salmiwati, 2003), the urgency of multicultural-based Islamic religious education learning in schools (Muliadi, 2012), integration of values in multicultural based learning in elementary schools (Rahmawati, 2017), character values in multicultural based Islamic religious education (Ismail, 2013), multicultural learning applications in Muhammadiyah Elementary School (Syahid, 2013), multicultural religious education (strategic effort to avoid radicalism (Susanto, 2006). Research (Rohinah, 2014), 
multicultural-based Islamic religious education (PAI) learning model as an effort to cultivate character in students. Multicultural research is also widely used in other research than Islamic education is like a pad a social study learning in Elementary Schools (Sudrajat, 2014), Language learning (Ninsiana, 2017).

Furthermore, previous research by (Harto, 2014), Some of the findings of this study are: the approach to learning religious education applied in educational institutions needs to be reformulated and adjusted to the multicultural context. The paradigm of religious learning adopted so far needs to be changed so as not to make people become intolerant, exclusive, selfish, narrow-minded, and oriented to individual piety. In addition to the educational paradigm; to think, to do, and to be, the educational paradigm; to live together is also needed so that the nuances of multicultural life can really be created in the learning process.

Research by (Kosim, 2010), Islamic Education based on multiculturalism (a study of PAI subject texts in senior high school). This paper presents the study on multicultural education focusing on PAI Textbook in Senior High School. Conceptually, subjects with multicultural education are adequate, especially on the material relating to aqidah, history and the Holy Qor'an

Based on observations, explanation of the description and previous research above, that the recent multicultural education is being discussed from the various problems that hinder it. In addition, the social problems, multicultural education is also related with learning processproblems. Within the framework of learning strategies, cultural-based learning can encourage imaginative, metaphorical, creative thinking, and culture-conscious processes. Nevertheless, the use of local culture (ethnicity) in cultural-based learning is inseparable from the various problems in each component of learning, since the initial preparation and implementation. Some early issues of multicultural learning in the preparation phase include: (i) Teachers are less familiar with their own culture, local culture and learners culture; (ii) Teachers have less understanding in mine learners' culture, especially in the context of the subjects to be taught; (iii) Teachers have low ability in preparing tools which can stimulate the learners' interest, memory, and re-introduction to their cultural repositories in the context respective cultures as well as in the dimensions of the learning experience gained. Refers to those current cases the writer is interested in doing research. Based on 
the explanation above, this study aims to describe how multicultural content-based islamic educational content in Senior High School in Bandar Lampung.

\section{THE RESEARCH METHODS}

This research was done through qualitative approach, which refers to the case study. According to Yin, the corresponding study is used in research involving a phenomenon that is not separate from the context of the environment. This research can also help researchers to understand the complex issues in a broad context (Konting, 2005). Majid Konting states that case study is an intensive study of a small social unit, such as individuals, families, within an organization. Majid Konting holds that although the units involved in the research are small but the results obtained are very profound. The research type in this research is single-case single-site exploratory case study. Single-case refers to one unit of analysis, whereas single-site refers to a single research site (Yin, 2009). The use of this research allows researchers to obtain the depth various results related to the problems of study (Creswell, 2010). Using this approach, researchers were able to recover data from all subjects who participated in the study (Yin, 2009).

In this study, the researcher can use various methods in data collection, such as group interviews, individual interviews, document analysis and interpretation. Research subjects involve four teachers who have seven to twenty years of teaching experience. Here, the social situation refers to the school situation, the subjects are the student, the teacher, and the object is the instruction or learning process of Islamic Education. The data collection procedure used observation, interview (unstandardized interview), some structured interview or active interview, casual interview, then using documentation method, then analyzed data using data reduction, data presentation.Furthermore, the data were analyzed qualitatively using NVIVO 10.0

\section{THE RESULT OF THE RESEARCH AND THE DISCUSSION}

The result of study showed that the content of Islamic-Based Multicultural Education Learning is: Distinguishing the concept of aqidah and muamalah; Designing material by applying multicultural and emphasizing the principle of equality (Equality); Making culture as content, and the concept of Islam Rahmatanlillalamin. 
In detail it can be seen as follows:

\section{Figure 1.1}

Research Results of Learning Content Of Islamic Education Based On Multikultural In Senior High School In Bandar Lampung

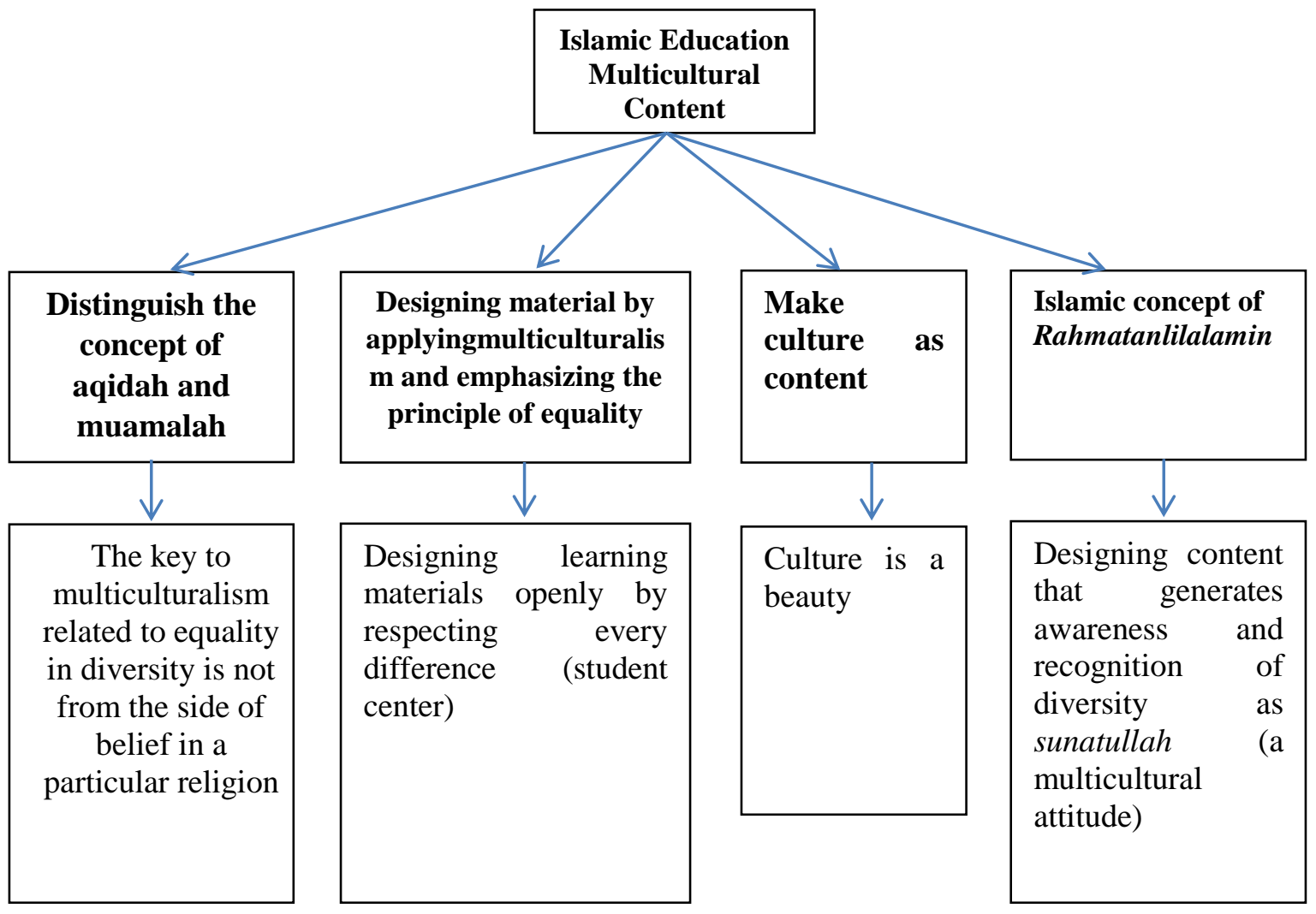

Based on the results of research above showed that cultural diversity didn't t become an obstacle for teachers to teach Islamic Eduaction. In fact, it became uniqueness as well as to increase knowledge about mutual understanding between cultures with each other. In fact, Religious education is as space for negotiating coexistence of various religious groups in Indonesia, which was a multicultural society (Rissanen, 2012). The role of multicultural education could be done by teachers who were the providers of knowledge materials. Thus, Islamic education to non-Muslim students was urgently needed (Omar, Noh, Hamzah, \& Majid, 2015). The Qur'an specifically mentions that the concept of human diversity was sunnahtullah (Omar et al., 2015). In recent years, it had been seen that multicultural education had a huge amount of education (Cirik, 2014). 
Some theories showed that learning process in schools influence ta content of learning needed to formulate a learning content of a study immediately formulate the content of learning aqidah and muamalah, Designing material by applying multicultural and emphasized a principle of equality (Equality), Making culture as Content, and the concept of Islam Rahmatalillalamin,

As well as the results reinforced by research (Kosim, 2010), the subject matter of multicultural education is mainly in the aspects of morals, history and the Qur'an. In addition, throughout the discussion of PAI textbooks, there are often expressions that lead to multicultural education, although the standard of competence is not directly related to multicultural education. Thus, multicultural education in PAI text in senior high school is sufficient

\section{CONCLUSIONS AND SUGGESTIONS}

The result of the research shows that content learning of islamic-based multicultural education is: Explaining the concept of aqidah and muamalah, Designing material by applying multicultural and emphasizing equality principle, making culture as Content, and concept of Rahmatalillalamin Islam In relation to multiculturalism of some material PAI that need to be taught with great emphasis are as follows: (i). The Teachings of Compassion According to Zuhairi Misrawi and Novriantoni, love becomes an applicable doctrine and is praxis. As an internal mechanism, compassion is important in the midst of any difference should be based on compassion, so that differences can not lead to social conflict. Differences and diversity of Muslims must be framed with the spirit of affection. Compassion must be an external mechanism, especially in the relations of Muslims with other people. Islam as a religion comes with a broad context necessitates the presence of sympathy towards religion and other groups it is necessary openness and the desire to live together peacefully and safely. (ii). The Doctrine of the Brotherhood The concept of brotherhood that Islam wants to uphold is a kind of nondiscriminatory fraternity. This kind of brotherhood should be strived on the basis of virtues such as justice, equality, tolerance, and away from the atmosphere of arrogance. The Islamic teachings on brotherhood do not recognize the boundaries of religion. Even in its history, Islam still encourages its people to establish good relations, even with people of different religions and worldviews in order to create a harmonious and 
dynamic situation. Basically the standard of friendship and hostility in Islam is not a factor of religion or beliefs solely in encouraging Muslims to act confrontational toward other people. The factors that determine the trajectory and hostility in the cross-history are more sociological or due to certain socio-political conditions. This means that the concept of a non-discriminatory fraternity that is open, elastic, liquid, and does not deny other groups, Muslims achieve and donate humanitarian civilization gloriously. Building a non-discriminatory situation is so important that in pluralism there is no "marginal feeling" in any quarters. (iii). The Doctrine of Peace is understood by the only heavenly doctrine of the heavens. God is called the creator of peace. Interpreting Islam as a peace, actually in line with the essence of Islam itself. The authentic thing in Islam is peace. Peace theology is a religious treasure that must be implanted to every individual, so that Islam is living peacefully and understanding diversity. The spirit of true peace becomes a culture that adorns everyday life. Every individual, family, society in various ethnic, ethnic, racial, and religious groups must work together to raise the doctrine of peace to the surface. Therefore, peace must always be preserved. It also serves as a framework for multicultural education to cope with the emergence of "antipeace" actions. (iv). The Doctrine of the Maslahat, there are five points of this maslahat commonly referred to as alkulliyat al-khamsah or the five souls ofmaslahat, these are keeping religion, keeping the soul, keeping reason, keep the offspring and keep the treasure. These five maslahat, as propounded by Imam Syatibi, are considered primary for humans. Islam holds these five souls. To carry this idea Nasr Hamed Abu Zayd put forward three principles, namely; 1) the principle of rationalism as opposed to fanaticism, because fanaticism is the source of ignorance, 2) the principle of liberalism, or the notion of freedom as a fundamental need for the Muslim state, and 3) the principle of justice that culminates in the dreams and dreams most "far from the fire" in the country - Muslim countries. As a note that for liberalism still oriented to Islam that has Islamic norms and procedures in this context morality karimah in various aspects. The necessity of this teaching cannot be separated to narrow the understanding of Islamic radicalism, with the rationalism of the Islamic world can further develop thinking and able to eradicate socio-political-economic ignorance, with elegant and elastic climate liberalism allows Muslims to develop all their potential so assured the 
moralistic, ethical and religious life processes of society are more prosperous and secure.

The suggestions of the research that (i). In Learning Islamic Based on Multicultural Education is needed support by various parties, especially from Islamic education experts and teachers in order to create and grow tolerance among the academic community; (ii). There needs to be increased cooperation between Islamic Education Teachers with general teachers and religious institutions to increase religious tolerance especially among teachers and students. 


\section{REFERENCES}

Cirik, I. (2014). Investigation of The Relations Between Objectives of Turkish Primary School Curriculums and Multiculturalism. Procedia-Social and Behavioral Sciences, 116, 74-76.

Creswell, J. W. (2010). Research Design: Pendekatan Kualitatif, Kuantitatif, dan Mixed, trans. Achmad Fawaid. Yogyakarta: Pustaka Pelajar.

Harto, K. (2014). Pengembangan Pendidikan Agama Islam Berbasis Multikultural. AlTahrir, 14(2), 411-431.

Ismail. (2013). Nilai-Nilai Karakter Dalam Pendidikan Agama Islam Berbasis Multikultural. Tadrîs, 8(2).

Konting, M. M. (2005). Kaedah Penyelidikan Pendidikan. Kuala Lumpur: Dewan Bahasa dan Pustaka.

Kosim, M. (2010). Pendidikan Agama Islam Berbasis Multikulturalisme (Studi Teks Mata Pelajaran PAI di Sma). Tadrîs, 5(2).

Lash, S., \& Featherstone, M. (2002). Recognition And Difference: Politics, Identity, Multiculture. London: Sage Publication.

Muliadi, E. (2012). Urgensi Pembelajaran Pendidikan Agama Islam Berbasis Multikultural di Sekolah. Jurnal Pendidikan Islam, I(1), 55-68. https://doi.org/10.14421/jpi.2012.11.55-68

Mulyana, R. (2011). Mengartikulasikan Pendidikan Nilai. Bandung: Alfabeta.

Nasional, D. P. (2005). Kamus Besar Bahasa Indonesia. Jakarta: Balai Pustaka.

Ninsiana, W. (2017). Pendekatan Multikultural Dalam Pembelajaran Bahasa Inggris Melalui Media Dongeng pada Anak Usia Dini. Elementary, 3(Januari-Juni), 41-52.

Omar, N., Noh, M. A. C., Hamzah, M. I., \& Majid, L. A. (2015). Multicultural Education Practice in Malaysia. Procedia - Social and Behavioral Sciences, 174, 1941-1948.

Rahmawati, R. (2017). Integrasi Nilai Dalam Pembelajaran Berbasis Multikultural di Sekolah Dasar. Elementary, 3(Januari-Juni), 31-39.

Rissanen, I. (2012). Teaching Islamic education in Finnish schools: A field of negotiations. Teaching and Teacher Education, 28(5), 740-749.

Rohinah. (2014). Model Pembelajaran Pendidikan Agama Islam (PAI) Berbasis Multikultural Sebagai Upaya Penanaman Karakter pada Siswa Sekolah Dasar Sanggar Anak Alam (Salam) Nitiprayan Kasihan Bantul Yogyakarta. Pendidikan Agama Islam, XI(1), 269-288.

Salmiwati. (2003). Urgensi Pendidikan Agama Islam Dalam Pengembangan Nilai-Nilai Multikultural. Jurnal Al-Ta'lim, 1(4), 336-345.

Sudrajat. (2014). Pendidikan Multikultural untuk Meningkatkan Kualitas Pembelajaran IPS di Sekolah Dasar. JIPSINDO, 1(1), 1-19. 
Supriatin, A., \& Nasution, A. R. (2017). Implementasi Pendidikan Multikultural Dalam Praktik Pendidikan di Indonesia. Elementary, 3(Januari-Juni), 1-13.

Susanto, E. (2006). Pendidikan Agama Berbasis Multikultural (Upaya Strategis Menghindari Radikalisme ). KARSA, IX(1).

Syahid, A. (2013). Aplikasi Pembelajaran Berwawasan Multikultural di Sekolah Dasar Muhammadiyah 3 Palu. ISTIQRA', 1(1).

Tafsir, A. (2004). Metodologi Pengajaran Agama Islam. Bandung: PT. Remaja Rosdakarya.

Widisuseno, I. (2012). Pendidikan Berbasis Multikulturalisme Suatu Upaya Penguatan Jatidiri Bangsa. HUMANIKA, 15(9).

Yin, R. . (2009). Case Study Research: Design and Methods (Applied Social Research Methods) (4th Editio). London and Singapore: Sage Publications. 